\title{
The Transition from Professional Engineering Practice to Academic Practice:
}

\author{
A Case Study \\ Abel Nyamapfene \\ Faculty of Engineering Science \\ University College London \\ London, United Kingdom \\ a.nyamapfene@ucl.ac.uk
}

\begin{abstract}
Engineering schools in the UK are increasingly adopting learner-centred, authentic learning approaches such as problem and project based learning to address the perceived lack of employability skills in engineering graduates. These methods are labour- and capital-intensive, and these demands for workready graduates are taking place in a period of real cuts in perunit student funding from government. To address these funding gaps, universities are increasingly focussing on securing research funding, leading to a preference for research active academics at the expense of academics with industrial experience. To plug these skills gaps, engineering schools are increasingly reliant on practitioners to teach on industry-focussed talks. However, the integration of practitioners into academic environments has not been smooth. In this paper I adopt a theoretical framework inspired by Bourdieu and Archer to identify the constraints faced by practitioners when they move into academic roles.
\end{abstract}

Keywords - teaching-only academics; REF/RAE; practitioneracademics; research intensive institutions

\section{INTRODUCTION}

Employers in the UK increasingly feel that there is a growing chasm between engineering courses taught in universities and industry demands for graduates with employability skills [1]. To address this gap, engineering schools are increasingly adopting learner-centred, authentic learning approaches such as problem and project based learning [2]. However, because of decline in government per unit student funding, universities are placing more emphasis on securing research funding. For instance, in the UK this has led to a preference for academics with the necessary research skills to secure research grant and to meet the requirements of the Research Excellence Framework, a mechanism used by the UK government to determine the allocation of research funding to universities [3].

The pursuit of research income by universities has inadvertently led to a decline in the number of academics with the industrial experience needed to effectively deliver learnercentred, authentic learning approaches such as problem and project based learning [4][5][6]. Engineering schools have attempted to address this shortage of practical engineering skills in their teaching by hiring experienced engineers on teaching-only contracts. However, the integration of practitioner-academics into engineering schools has not been smooth [7].

In this study I adopt Elder-Vass' [8] synthesis of Archer's [9] and Bourdieu's positions to theorise that the higher education social environment determines the locus of opportunities and possibilities for individuals working within it, and that individuals respond differently to social environment dynamics based partly on their personal dispositions, abilities and capacity to act. Such a position has enabled me to explore the following research question: What are the lived experiences of practitioner-academics in a research intensive institution, and what structural issues support or inhibit their academic roles within such institutions?

\section{RESEARCH METHOD AND PARTICPANTS}

\section{A. Research Method}

I adopted a case study approach in my investigation of teaching-only academics within research intensive institutions in the UK. According to Bassey [10], a case study enables a phenomenon to be studied to significant depth within its own natural context. Because of this closeness to real-life situations, and the wealth of detail that it generates, a case study makes it possible for a researcher to gain insights into the deeper causes behind a given problem and its consequences in a particular situation [11].

I chose the life history approach in my study because it is ideal for shedding light on the "interactive relationship between individuals' lives, their perceptions and experiences, and historical and social contexts and events [12]. By studying an individual's life alongside the historical and social contexts intersecting with that individual's life, it is possible to gain an understanding of the choices, contingencies and options that were available to that individual, both in the past, and in the present [13].

Chase defines life history as "an extensive autobiographical narrative, in either oral or written form, that covers all or most of a life" [14]. According to Clandinin [15] human beings "both live and tell stories about their living". It is through living, telling and talking about these stories that "we create meaning in our lives as well as ways we enlist each other's 
help in building our lives and communities" [15]. Hence, through narrative, we can discern how people live and act in a given setting, and the particular nature of the happenings that they experience can help to shed light on their beliefs, desires, theories and values [16].

I elicited the life histories of the research participants by conducting one-to-one conversational interviews with them. A conversational interview style allows interviewees to freely use narrative in their responses [12]. and this is ideal because, as human beings, we naturally "... tell stories about our life and our 'self', or rather our 'selves', as a sort of reflective interpretative device, with a view to understanding who and what we are and the things that happen to us" [12]. My study methodology can therefore be described as consisting primarily of narrative enquiry carried out within a life history context.

\section{B. Choice of Research Participants}

My study focussed on a group of teaching-only academics who had previously worked in industry and were now working in the faculty of engineering of a research intensive institution in the South of England. I have coined the term "practitioneracademics" to distinguish these academics from other academics. The case study institution is a member of the Russel Group of universities, an elite grouping of the UK's research intensive universities. To preserve the anonymity of the research participants, I shall refer to the institution using the pseudonym "the Elite Southern University."

Practitioner-academics are normally recruited by the institution into the teaching fellow academic category. This is a category reserved for teaching-only academics. At the time of the study, the teaching fellow category had three progression levels, namely the teaching fellow grade, the senior teaching fellow grade, and lastly the principal teaching fellow grade. The teaching fellow grade is equivalent to the associate lecturer grade on the research and teaching academic category, whilst the senior teaching fellow grade is equivalent to the lecturer grade and the principal teaching fellow equivalent to the senior lecturer grade. At the time of the study, there was no professorial grade for academics on the teaching fellow category.

The teaching-only academic category came into being primarily as a result of the research assessment exercise (RAE), which has now been replaced by the Research Excellence Framework (REF) [17]. The RAE/REF is a government mandated, academic peer assessment exercise for assessing and monitoring the quality of university research within the UK. It is used to determine the distribution of research funding amongst higher education institutions. This makes it very important from the perspective of participating institutions. Prior to the RAE/REF the study institution had a unitary academic job family. In the words of one of the research participants:

I stayed on the lecturer grade until about 2006, when they brought in the teaching fellow grades. They made us switch across to the teaching fellow grades. We were forced to. We had no choice. That was when they decided to make a distinction between teaching-only staff and research staff. It was to keep us out of the REF basically. At the time everyone who was teaching only was made a teaching fellow. [PTF2 Own Story, lines 85-89]

In this study I focussed on practitioner-academics employed at the principal teaching fellow category, the highest rank that teaching-only academics can attain in this university. Such individuals are likely to have progressed up the academic ladder from the lower levels, implying that they have been in higher education for a long enough period to have first-hand experience of how the teaching-only academic role has evolved over time. In addition, the principal teaching fellow role comes along with managerial responsibility for departmental teaching in capacities such as programme director or departmental lead for learning and teaching. Being in such a position would enable them to gain insights into the relationship between teaching and research, and into the departmental and institutional beliefs on the role of teaching in research-intensive universities.

At the time of the research, there were twelve principal teaching fellows across the faculty, and of these twelve, five had worked in industry prior to joining the faculty. All of the five were programme directors on one or more undergraduate courses, with primary responsibility for the content and structure of their degree programmes, and for all the teaching on the programme.

To ensure the confidentiality and anonymity of participant data, I closely followed the guidelines from the UK Data Archive. All personal information belonging to participants was stored in a separate location to the interview data and all the data files were password-protected. To keep track of the participants, I used a simple alphanumeric identity code to number the participants as well as to encode their academic career grades. I did this by encoding the principal teaching fellows as PTF1, PTF2, up to PTF5 respectively. At the time of the interviews, the youngest participant, PTF1, was a 33year-old male, and the oldest participant, PTF4, was a 68-yearold male. The remaining three were all females, with two, PTF2 and PTF3, in the age group 55 to 60, and the last one, PTF5, being in her mid-30s.

\section{RESULTS AND ANALYSIS}

\section{A. Reasons for going into Academia}

All the research participants expressed the view that they came into academia because they love to teach, and most feel that as experienced engineers they have an obligation to teach the next generation of engineers. The response by PTF4 to my question asking him why he chose to undertake teaching at the institution is typical of the responses made by all the research participants:

I suppose it's because teaching is what I have always done. I haven't had a history of doing research. I enjoy the interactions with students. I feel very strongly with a vocational degree we are preparing them for careers. So I feel that part of my job is to prepare them for that, and to give them an academic slant on subjects, as 
well as a practical slant on what the subjects are all about so that when they hit industry they are used to the terminology and to the techniques. So that's what I enjoy, and that's what I would rather do. [PTF4 Own Story, lines 81-87].

\section{B. The need for practitioner-academics in the institution}

There is a general recognition amongst the practitioner academics that, given their practical experience, they have a role to play in engineering and other programmes of a vocational nature.

I guess just having that practical experience helps. Just having that kind of slightly wider commercial experience of working with people from completely different disciplines as well probably helps. [PTF5 Own Story, lines 239241]

Moreover, the practitioner-academics that I interviewed generally believed that having someone with practical experience delivering teaching in engineering and other vocational programmes was now a must, and not just a nice thing to have:

They recruit specialists on the teaching fellow route, because no architecture school is complete without practitioners. [PTF3 Own Story, lines 158-160]

PTF1, who is a structural engineer, observed that one of the main reasons that he had been recruited to the civil engineering department was that owing to the need to focus on the REF, the department had concentrated on recruiting research active staff with little or no experience in engineering practice. His recruitment was meant to fill in the skills gap that was emerging as older academics with industrial and research experience, were reaching retirement age:

There are now very few people who are good at both [academic research and engineering practice], because what people tend to do, typically, is they start early on a research career. $\ldots$ and so the retiring guy I was replacing was one of those persons who could do both well. [PTF1 Own Story, lines 95-107]

Practitioner-academics have proven to be useful to the institution, and some departments now express a preference for them instead of traditional research and teaching academics in most teaching-focussed roles:

Then more teaching fellows were hired, because, I would like to say, we were good. So now there are 10. They said, "These people are effective, let's hire teaching fellows as opposed to a lecturer because we want this person to do more teaching." So there is more of us now. There are 10 or 12 of us. [PTF1 Own Story, lines 230-233]
However, despite their contributions to departmental teaching, practitioner-academics feel that they are not as appreciated as research-active academics:

I do have a feeling that teaching is undervalued at the Elite Southern University as opposed to research. There is much more emphasis on research. [PTF4 Own Story, lines 70-71]

\section{Experiences of marginalisation}

There is a general feeling that research takes preeminence over teaching, and this leads to practitioneracademics being marginalised within the department and faculty. PTF4 has increasingly experienced this marginalisation as his department, the Built Environment has sort to establish a research profile:

As the school has become much more active in research, a lot of the activities, a lot of the discussions exclude the teaching fellow. So we do feel on the edge of the school, if you like. I wouldn't feel we are undervalued in a sense because everybody appreciates the volume of teaching that teaching fellows do, and how this takes the load off academics to allow them to focus on research. But I would definitely feel that there is a feeling in the school that there are full time members, and also on the fringes there are teaching fellows as well. Second class citizens is putting it too strong, but there is a definite feeling of not being in the mainstream. [PTF4 Own Story, lines 140-147]

Marginalisation is more acutely felt in career progression and promotion, where the general perception amongst practitioner-academics is that the institution's progression and promotion processes are more inclined towards research and teaching academics as opposed to those on teaching-only contracts:

The criteria, I don't believe are correct. I think the criteria are very research focused; the criteria are very research based. For the principal teaching fellowship that was the complaint that PTF5 and I had when we were doing it. It's like they were even asking us for a list of publications, and we are like we don't have that many, you know, there is a bit here and a bit there. If this is a separate track why isn't there a separate list of criteria. We think there is fundamental problem with the criteria, and that the criteria needs to be revised to reflect the kind of work that teaching fellows actually do here, and in that case a lot of it is managing programmes. [PTF1 Own Story, lines 209-216]

Whilst some managers would consider putting a teaching -only academic forward for promotion, there are still a number of departmental managers who would resist such a move, as evidenced by the experiences of PTF3: 
I also approached my head of department about the possibility of making an application for senior promotion based on my teaching, and based on my work on the development of teaching and learning, and he laughed and told me that I was basically delusional, and that as an individual with no publications basically "What planet are you on?" Oh yes, we had a period of not being friends. [PTF3 Own Story, lines 102107].

\section{Structural issues to career progression for practitioner- academics}

The practitioner-academics felt that the institution had not properly thought out career progression pathways for academics on teaching only contracts. For instance, PTF2 feels that teaching-only academics are only appointed to fill a specific role with limited career growth prospects, which is not the case with those on traditional research and teaching academic contracts:

Teaching fellows do tend to get appointed for a specific job in hand. You appoint a teaching fellow to do a specific task. So if that task is no longer there what happens to the person, they may end up losing their job. This is not the case with lecturers. [PTF2 Own Story, lines 380-383]

Even after a practitioner-academic manages to secure promotion, they are still expected to undertake the same role as they were recruited for, in addition to the managerial tasks that are placed on them after being promoted. For instance, PTF1 feels that this has constrained him from undertaking more strategic roles consistent with his new role as a principal teaching fellow:

There is lots of opportunities that I would need to be able to take, but for me to be able to take those opportunities they would need to put other staff into taking on some of my work, and that's where the issue is at the moment. It's this balancing of workload as you move on. A lot of people are being promoted, but are effectively doing the same job. They are even more stretched. PTF5 is very stretched. PTF5 is just doing more and more and more. What you would need to have is to have other people and resources to support your role so that you can start to do the things you need to do to hit that level. [PTF1 Own Story, lines 292-299].

\section{E. Belonging or not belonging?}

Despite all these problems, practitioner-academics appreciate the importance of research to the survival of both their departments and the institution:

15 or so years ago, a new head of department with a view to strengthen the school decided that he would try and limit part time teaching and he would try and grow the full-time staff. This was because there were very few people doing research, and so we were very vulnerable ... I say we were vulnerable because Elite Southern University is very focussed on research and we are a school that does little research. When it comes to the RAE we have got very little to hand in. As a school that has very little research, it would not take very much for somebody to say, "If you are not research active you don't match Elite Southern University's profile, so we'll close you down”. [PTF4 Own Story, lines 120-134]

In addition, despite some of the negative experiences they have experienced within the institution, most of the practitioner-academics feel that they are more valued within the institution than before, and that they still have a role to play within the institution and would like to stay on:

I feel more valued today than at any point over the 12 years I have been here. [PTF2 Own Story, line 254]

There is definitely a place for me here. Sure, I've rye smiles when people are shocked that there is space in a research intensive university for somebody like me. [PTF2 Own Story, lines 344345]

However, other practitioner-academics do not view themselves as full-time academics, but rather as practitioners who maintain their professional roles in industry in addition to taking up teaching roles within universities. PTF4 is of this view:

So I agreed with him, but I would spend two days at Elite Southern University and three days in industry. So for the last 20 years, because that was 20 years ago, that's what I have done. So for about 15 years I was running the undergraduate programme in project management for construction, and the rest of the week I was working in industry. Now, for our degree, which is a vocational degree, that arrangement was perfect - that somebody who executed it in real life could then come and teach here. So if you would like, I have not had an academic career. I have always been somebody from industry that has taught. [PTF4 Own Story, lines 34-41]

Similarly, PTF1, although he is currently a full-time academic, unlike PTF4, feels that his current role is only a temporary phase in his life as he intends to go back to industry.

I imagine that I will always be back and forth, so I don't see myself staying here and working here for another 40 years, 30 years till I retire. I need to go back and forth, whether that is a couple of days a week here, a couple of days a week there, whatever it is. I will certainly need to move back, because I don't think I will be as good at what I 
do, which is teach engineering, unless I am practising it. [PTF4 Own Story, lines 309-313]

\section{CONCLUDING REMARKS}

This study reveals that professional practitioners who leave industry to take up academic roles within higher education generally have a high enthusiasm for teaching. Such academics primarily view themselves as professional practitioners who are doing their profession a service by engaging in teaching the next generation of professionals. They are intrinsically motivated to teach. However, as the practitioner-academics enter the university system, they come up against a formidable adversary. This is none other than the entrenched research culture within higher education. As this study shows, research is the dominant narrative within universities, and it is the prism through which every activity and individual within the university system, particularly in research intensive universities, is judged and evaluated. This includes discussion on who should be promoted, and what counts as promotion.

Even though some practitioner-academics are particularly resilient, as indicated by this sample of practitioneracademics in this study, still there are perceptions of a binary division between those engaged in research and those who are primarily in the university to teach. Özbilgin and Woodward have coined the dual term othering-and-belonging to explain a binary fissure that is experienced by outsiders when they engage with a well-established social system [18]. In this study, practitioner-academics are the outsiders, and their ability to stay on in the university system and make a positive impact on university teaching depends largely on the extent to which the university system is prepared to mitigate the negative impact of its entrenched research culture. This does not mean that research is bad. Rather, this study suggests that universities need to become more inclusive if they are to excel in both research and teaching to the benefit of society. At a minimum, institutions need to actively change the narrative within departments so that people engage in conversations on both teaching and research.

In general teachers' well-being has a significant impact on the quality of their teaching. At a minimum, the institution should provide clear steps for career progression for practitioner-academics. Secondly, practitioner-academics view themselves primarily as practitioners, and not as academics. As such they are likely to maintain their professional roles in industry whilst also teaching, or, as is the case of PTF1, they may want to move back to industry after a few years in teaching, and then move back to teaching again. This suggests that institutions need to be sufficiently flexible in their recruitment practices to ensure that such practitioners are able to engage in teaching whilst developing their professional careers.

\section{REFERENCES}

[1] The The Institution of Engineering and Technology, (IET). (2015). "Skills and Demand in Industry - 2015 Survey". City: The Institution of Engineering and Technology: London.

[2] Jollands, M., Jolly, L., and Molyneaux, T. (2012). "Project-based learning as a contributing factor to graduates' work readiness." European Journal of Engineering Education, 37(2), 143-154.

[3] Harley, S. (2002). "The Impact of Research Selectivity on Academic Work and Identity in UK Universities." Studies in Higher Education, 27(2), 187-205.

[4] Alpay, E., and Jones, M. E. (2012). "Engineering education in researchintensive universities." European Journal of Engineering Education, 37(6), 609-626.

[5] Graham, R. (2015). Does Teaching Advance Your Academic Career?: Perspectives of Promotion Procedures in UK Higher Education.

[6] Tennant, S., Murray, M., Forster, A., and Pilcher, N. (2015). "Hunt the shadow not the substance: the rise of the career academic in construction education." Teaching in Higher Education, 20(7), 723-737.

[7] Craig, N., Tennant, S., Murray, M., Forster, A., and Pilcher, N. "The role of experienced practitioners in engineering education: the end of an era?" Presented at 6th International Symposium for Engineering Education.

[8] Elder-Vass, D. (2010). The Causal Power of Social Structures: Emergence, Structure and Agency: Cambridge University Press.

[9] Archer, M. S. (2000). Being human: The problem of agency: Cambridge University Press.

[10] Bassey, M. (1999). Case study research in educational settings: McGraw-Hill Education (UK).

[11] Flyvbjerg, B. (2006). "Five misunderstandings about case-study research." Qualitative inquiry, 12(2), 219-245.

[12] Goodson, I. F., and Sikes, P. (2001). Life History Research in Educational Settings: Learning from Lives, Buckingham, Philadelphia: Open University Press.

[13] Goodson, I. (2008). Investigating the teacher's life and work, Rotterdam/Taipei: Sense Publishing.

[14] Chase, S. E. (2007). "Multiple lenses, approaches, voices." Collecting and interpreting qualitative materials, 57(3), 651-679.

[15] Clandinin, D. J. (2006). "Narrative inquiry: A methodology for studying lived experience." Research Studies in Music Education, 27(1), 44-54.

[16] Bruner, J. (1991). "The Narrative Construction of Reality." Critical Inquiry, 18(1), 1-21.

[17] HEFCE. (2012). "Research Assessment Exercise (RAE)". City: HEFCE.

[18] Özbilgin, M. F., and Woodward, D. (2004). "Belonging'and 'otherness': sex equality in banking in Turkey and Britain." Gender, Work \& Organization, 11(6), 668-688 